\title{
A REVIEW AND CONTENT ANALYSIS OF MATHEMATICS TEXTBOOKS IN EDUCATIONAL RESEARCH
}

\author{
Cheng Chieh Chang, Sari Muthia Silalahi \\ National Taiwan Ocean University, Taiwan \\ E-mail: sarimuthiasilalahi@gmail.com
}

\begin{abstract}
Research collected and reviewed a number of empirical studies in the field of educational research regarding the analysis of mathematics textbooks to provide summary and overview the information there in. The questions were identified via Google Scholar and collected from different data sources. A total of 44 papers published from 1953 to 2015 were selected based specific criteria, with 24 articles include in the SSCI database. Descriptive statistics were used to evaluate and interpret the results. A perspective on the learning analysis methods was used to collect studies and showed the mathematics textbooks analyzed were investigated under four themes: The analysis of standards, distributive property, language in mathematics, and others. School's level which is investigated textbooks: Kindergarten, elementary, junior school, and senior school. Subjects covered in the mathematics textbooks included algebra and arithmetic, geometry, measurement, data analysis and probability, number and operations, among others. Research found the most frequently discussed in perspective on learning was the analysis of the standards and the distributive property (15 studies), the most common subject was number and operations (16 studies), and the highest number in school's level was elementary school (18 studies). Nevertheless, fewer studies have been found to analyzing mathematics textbooks. Future research can pay attention for the relevant theoretical issues and collaborate studies in more perspective learning analysis.
\end{abstract}

Keywords: comparation of study, content analysis, mathematics textbooks.

\section{Introduction}

Curriculum of a school determines the structure and content of the materials taught to the student's answer is typically tailored to the needs of the teaching process experiences and needs of both students and teachers (Schmidt, McKnight, Valverde, Houang, \& Wiley, 1997). Efforts to examine curriculums through the large-scale cross system studies of the International Association for the Evaluation of Educational Achievement (IEA) began with the textbook analyses of the Third International Mathematics and Science Studies (TIMSS) curriculum studies (e.g., Schmidt, McKnight, Valverde, Houang, \& Wiley, 1997).Textbooks are provided to and used by students in order to support their learning with appropriate content and classroom activities that the students can engage with either personally or in groups. In this sense, textbooks are generally helpful to both teachers and students, with the true value of a given textbook being determined by the degree to which it contributes to students' education.

Mathematics is a subject of study that involves frequent usage of calculations and functions written out on paper, including the use of numbers, figures, theories, and proofs; it thus requires patience and perseverance in thinking critically and logically (Kilpatrick \& Swafford, 2002; Verschaffel \& De Corte, 1996).

Reasoning and understanding are critical to the learning of mathematics. Past studies have explored these critical factors by examining the following subjects: How students think logically and correctly, how students solve problems creatively while also adhering to the rules of mathematics, and the means by which mathematics concepts are communicated (such as, for 
Cheng Chieh CHANG, Sari Muthia SILALAHI. A review and content analysis of mathematics textbooks in educational research

PROBLEMS

OF EDUCATION

IN THE $21^{\text {st }}$ CENTURY Vol. 75, No. 3, 2017

236

example, via representation, discussion, drawing, reading, and writing) (Kilpatrick, Swafford, \& Findell, 2001; Kilpatrick \& Swafford, 2002; Verschaffel \& De Corte, 1996). These conclusions were reinforced by other finding and suggesting that there are several key components in learning mathematics: Correct knowledge of the bases of mathematics, the application from formula and evidence, accuracy in performing calculations, and reasoning accurately while using the mathematics in daily live (Kilpatrick \& Swafford, 2002). Among the key capabilities needed in using mathematics, one is the ability to solve problems, which itself requires the capacity to build mathematical thinking in order to analyze and conceptualize the formula used in problem solving. On the other hand is for teacher who uses the mathematical language to present and explain idea to the students by mathematics books and software.

The primary targets of education research in this area would be discussing and analyzing mathematics education, especially discussion and analysis of the teaching and learning processes for mathematics textbooks. To present the content of mathematics effectively, we require pedagogical content knowlwdge (PCK) (Shulman, 1986b) - which links content and pedagogy. Understanding of the given curriculum and pedagogy itself is the primary requirement for teachers, although other knowledge is also needed by teachers, including 1 . An understanding of the nature of students that allows, in turn, an understanding of their interests and abilities regarding topics that are difficult or interesting to learn, and 2. Knowledge of the ways in which a topic can effectively be presented to students. Such knowledge significantly affects the value of teaching efforts and students' ability to capture and digest the material to be learned. As such, knowledge of this type is what needs to be improved upon by teachers from day to day in their education efforts (Ball \& Bass, 2000).

The analysis of textbooks assists educational researchers in understanding the effectiveness of specific schemes and approaches, which can turn aid in understanding of what is required in terms of teaching and curriculum development. In mathematics education, mathematics textbooks play a particularly prominent role in guiding teachers on specific materials to teach. Simply put, mathematics textbooks help teachers to design and describe the topics of learning that will be covered in the classroom. Past studies investigating such textbooks haveincluded studies on the "content topiccoverage that is presented in textbooks" (Fuson, Stigler, \& Bartsch 1988; Westbury, 1992), "textbooks' pedagogical features" (Mayer, Sims, \& Tajika, 1995; Schmidt, McKnight, \&Raizen, 1997), the "curricular treatment of mathematics content" (Cai, Watanabe, \& Lo, 2002; Schmidt, McKnight, \& Raizen, 1997), and "exercise problems" (Fan \& Zhu, 2007; Li, 2000; Stigler, Fuson, Ham, \& Kim, 1986; Sugiyama, 1987).

So, this research, we focus on several key of variables of the mathematics textbooks identified by past studies: The area of learning concentration in mathematics textbooks, the subjects covered in mathematics textbooks and the degree level in school of the students for whom the textbooks are intended.

\section{The Research Aim}

By analyzing relevant empirical educational research studies published from 1953 to 2015, this study sought to summarize information from the past literature regarding the analysis of mathematical textbooks in order to address the following research questions:

1. What kinds of perspective learning were the most frequently analyzed by studies of mathematics textbooks?

2. What subject was investigated with the greatest number of studies of mathematics textbooks?

3. Which school's level were the most commonly analyzed in mathematics education researchers? 


\section{Methodology of Research}

\section{Papers Selection}

The studies reviewed in the present investigation were chosen through electronic sources. The literature investigated was not limited topublished studies because there have been relatively few studiesthat have analyzed mathematics textbooks. Rather, the documents collected were all produced between 1953 and 2015, and were located via Google Scholar searches ofvarious data sourcesfor educational research studies, including databases and publishers of both journal articles (ProQuest, JSTOR, Springer Science, and Routledge and Taylor \& Francis) and conference proceedings. Specific criteria were implemented to identify the collected research papers. Such as: "mathematics textbook analysis", "mathematics textbooks", "comparative analysis", "comparative study of mathematics textbooks", and "content analysis of mathematics textbooks". A total of 44 papers were selected based on the specific search criteria, and of those 44 papers, 24 articles were included in the Social Sciences Citation Index (SSCI) database.

\section{Coding Procedure}

Learning topics were coded and categorized according to fourth criteria. These rules guiding the research approach focused on how learning topic is presented in mathematics textbooks. The first criterion was focus on the analysis of standards: "the particular focus of the standards-based approach is to examine and indicate the development of the conceptual understanding and communication of mathematics over its memorization and rote learning in school" (Jitendra, 2005). The second criterion was focus on the using language/voice in textbooks. Haliday (1973) indicated this focus seeks to interpret the meaning of language in the context of its function. In other words, it examines how language is used and form has evolved, functional grammar analysis which provides a method of language analysis that enables for researcher to discuss the purpose and use of the language utilised based on three elements: Ideational function, interpersonal function, and textual function. The third criterion was focus on the distributive property. The National Mathematics Advisory Panel (2008) mentioned that "the distributive property (DP), along with the commutative and associative properties, has been recognized as a critical foundation for school mathematics", and that is involes the ability to "identify such features as commutativity, associativity, and distributivity".

Authors considered the studies in terms of the subjects taught in the mathematics textbooks they investigated, as well as thelevel in school for which the books were intended. In the first stage, the content of a selected paper was coded based on its focus in learning mathematics in order to specify different aspects of cognitive development and its application to education. Thus, coding scheme for analyzing perspective on learning included in each selected paper (Table 1). 
PROBLEMS

OF EDUCATION

IN THE $21^{\text {st }}$ CENTURY Vol. 75 , No. 3, 2017

238

Table 1. Perspective on learning in analysis of mathematics textbooks.

\begin{tabular}{|c|c|c|c|}
\hline Topics & Code Number & Sub Topics & lanation \\
\hline \multirow{5}{*}{$\begin{array}{l}\text { Analysis of the } \\
\text { standards }\end{array}$} & PS & Problem - solving & $\begin{array}{l}\text { "Problem-solving refers to, problem-solving } \\
\text { opportunities that encourage students to } \\
\text { solve interesting and challenging problems". }\end{array}$ \\
\hline & RS & Reasoning & $\begin{array}{l}\text { "Reasoning includes skills such as making } \\
\text { mathematical conjectures, exploring phe- } \\
\text { nomena by observing, examining inferences, } \\
\text { justifying findings, and developing math- } \\
\text { ematical arguments". }\end{array}$ \\
\hline & $\mathrm{CM}$ & Communication & $\begin{array}{l}\text { "Communication" refers to communicating } \\
\text { mathematical thinking coherently and clearly } \\
\text { to others using both verbal and written com- } \\
\text { munication". }\end{array}$ \\
\hline & $\mathrm{CN}$ & Connections & $\begin{array}{l}\text { "Connections refer to relating new material } \\
\text { to students' prior knowledge, skills, experi- } \\
\text { ences, and interests". }\end{array}$ \\
\hline & $\mathrm{RP}$ & Representations & $\begin{array}{l}\text { "Representations refer to illustrations (i.e., } \\
\text { diagrams, graphs, models, tables, pictures, } \\
\text { manipulatives, symbolic expressions) that } \\
\text { define mathematical relationships in order } \\
\text { to help students organize their thinking and } \\
\text { interpret mathematical situations." }\end{array}$ \\
\hline \multirow{3}{*}{ Language / Voice } & ID & Ideational function & $\begin{array}{l}\text { "The most commonly found processes within } \\
\text { the ideational function are material, mental } \\
\text { and relational". }\end{array}$ \\
\hline & IT & Interpersonal function & $\begin{array}{l}\text { "The interpersonal function examines the } \\
\text { social and personal relationships between } \\
\text { the author and others while establishing the } \\
\text { expression of the author's authority and the } \\
\text { relationship between the author and reader". }\end{array}$ \\
\hline & TF & Textual function & $\begin{array}{l}\text { "The textual function 'distinguishes a living } \\
\text { message from a little entry in grammar or a } \\
\text { dictionary." }\end{array}$ \\
\hline \multirow{3}{*}{ Distributive property } & MF & Mathematics feature & $\begin{array}{l}\text { "Single step required (S), Multi-step required } \\
\text { (M)" }\end{array}$ \\
\hline & $\mathrm{CF}$ & Contextual feature & $\begin{array}{l}\text { "Purely mathematical context in numerical or } \\
\text { word form (PM) including illustrative context } \\
\text { such as visual representation (IC)" }\end{array}$ \\
\hline & PR & Performance requirement & "Response type and cognitive requirement". \\
\hline Others & 0 & $\begin{array}{l}\text { This analysis considered the } \\
\text { use of the overall curriculum } \\
\text { and pedagogy in education } \\
\text { as well as the teaching and } \\
\text { learning process conducted } \\
\text { by the teacher in the class- } \\
\text { room. }\end{array}$ & \\
\hline
\end{tabular}

To estimate inter-coder reliability, we chosen $30 \%$ with random of the papers reviewed by any two researchers. To solve the issue of coding reliability, three researchers worked collaboratively together on the coding procedure. Disagreements were settled after discussions among the researchers. A reliability of 0.88 was ultimately achieved. That means the scores from the two scorers were highly correlated. 
In the second stage, all the papers were examined and evaluated according to the level of school that the textbooks investigated were intended such as kindergarten, elementary school, junior high school, and senior high school. In the last stage, all the papers were investigated according to the subjects were taught. Analysis allowed us to determine the issue which was the most widely analyzed by researchers when they have investigated the textbooks. This research is going to clarify the development of studies regarding the using of mathematics textbooks in education, and help researchers in the future when they want to analyze mathematics textbooks.

\section{Results of Research}

Mathematics textbooks hold enormous potential for supporting learning and teaching in the classroom, and the number of studies regarding mathematics textbooks has grown rapidly in the last few years. In this paper, the selected literature regarding mathematics textbooks were analyzed according to three main criterias.

\section{Perspective on Learning in Matematics Textbooks}

A key aspect of the standards-based approach emphasizes the development of conceptual understanding and reasoning over memorization and rote learning. This is because problemsolving, reasoning, communicating, connecting, and representing mathematical content are important goals across grade levels and content types. In this study, author decided to focus on these processes, and identified 44 studies that provided different information about the learning perspective of mathematics textbooks. These perspectives on learning were defined in four groups: The analysis of standards, the distributive property, language in mathematics and others.

Out of the 44 studies, 12 involved the analysis of standards, 15 considered the distributive property, 4 considered the use of language in mathematics and others 12 studies which is not including in "the analysis of standards", "the distributive property", and "the distributive property".

The 12 studies that considered the analysis of standards could be further sub-divided as follows: Problem-solving (6 studies), reasoning (3 studies), communication (no study), connection (1 study) and representation (2 studies). The studies that consider in the distributive property could be further sub-divided as follows: Mathematics feature (10 studies), contextual feature (no study), performance requiretment ( 5 studies). The studies that consider language in mathematics could be further sub-divided as follows: Ideational function ( 3 studies), Interpersonal function (no study), and textual function (1 study).

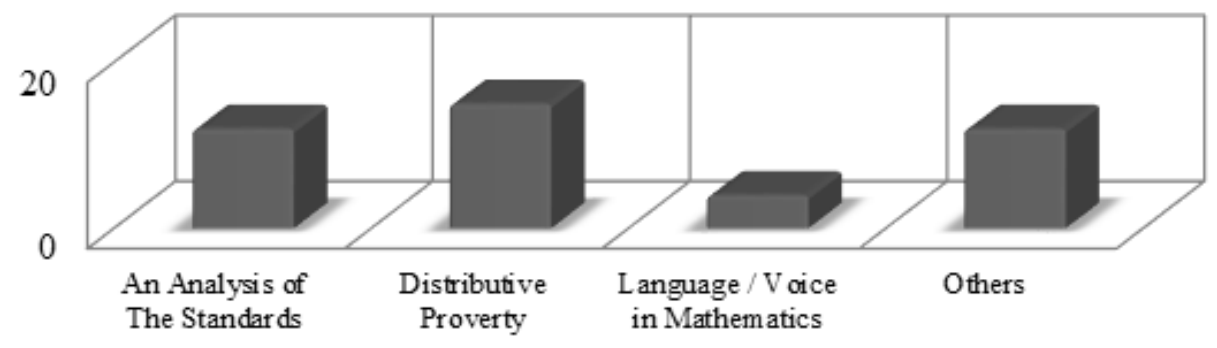

Figure 1: Some subjects are taught in the mathematics textbooks analyzed.

The result in figure 1 shows the analysis of standards and the distributive properties were the greatest topics in papers that authors have reviewed. In particular with regard to the analysis of standards, problem-solving was apparently the most important topic have given the number 
Cheng Chieh CHANG, Sari Muthia SILALAHI. A review and content analysis of mathematics textbooks in educational research

PROBLEMS

OF EDUCATION

IN THE $21^{\text {st }}$ CENTURY Vol. 75, No. 3, 2017

240

of amount which considered on it. This conclusion was also supported by previous research; for example, the National Council of Teachers of Mathematics (1989) noted that mathematical problem solving lies at the center in mathematics on an international basis. To emphasize this point, the NCTM stated that "problem solving should be the focus of the mathematics curriculum." Problem solving should be the primary focus of mathematics curriculum and instruction at each school level, and this centrality of problem solving should be introduced to educators, policy makers, and also teachers engaged in mathematics education. With regard to the distributive property, the Mathematics feature was the most likely for researched. As Li (2007b, 2008a) mentioned, the following points: 1. Discussion contents, 2. Creating a work plan or schedule for students, 3. The presentation and content exposure, and 4. Associating and linking aspects of content with one another. These four points were seen as critical in the manufacture of mathematics textbooks that support the ability of students to learn.

\section{Subjects in Mathematics Textbooks}

Berelson (1952, p.74) explained that content analysis is a method in which the main focus is on calculating the sequence and direction through which communication and written language are presented. The aim of this technique is to present results regarding the structure and content of specific textbook aspects, such as the pages and the cover of a given book. The technique also classifies mathematic lessons into five branches: Numbers and operations, measurements, geometry, algebra and arithmetic, and data analysis and probability. In the 44 studies reviewed, different information was reported regarding the subjects taught in the mathematics textbooks investigated. The topics of the mathematics textbooks investigated were defined in a number of distinct groups: Number and operations (14 studies), arithmetic and algebra (8 studies), geometry (2 studies), measurement (4 studies), data analysis and probability (2 studies), and others (14 studies).

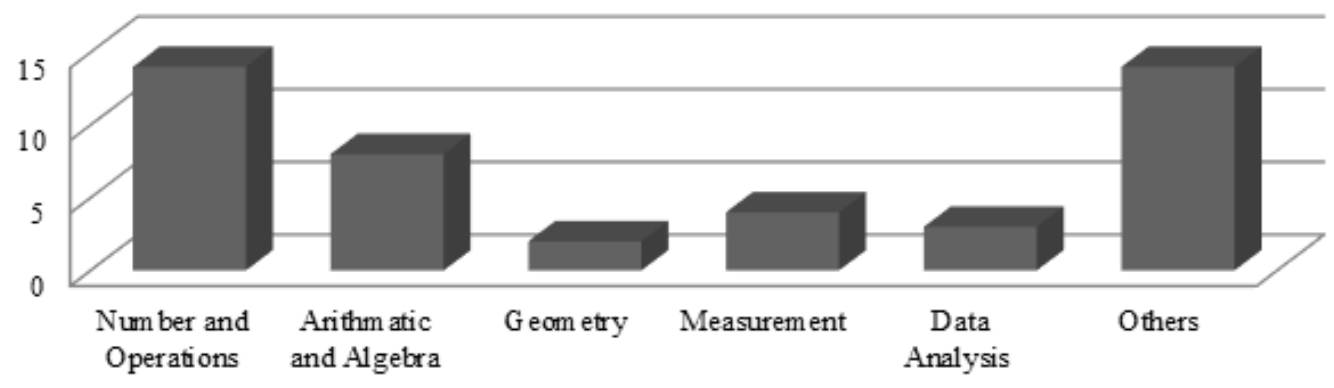

Figure 2: Some subjects are taught in the mathematics textbooks analyzed.

The results in Figure 2, shows that certain subjects attracted particular attention from researchers. Numbers and operations, as well as algebra and arithmetic, were the lesson topics that dominated the papers we reviewed. Authors found that addition and subtraction were the most analyzed topics. Related to this, Li and Kulm (2008) mentioned that as a specific mathematics content topic,"addition and subtraction are well conceptualized and organized for teaching and learning". Addition and subtraction are every important topics for both teachers and students. Indeed, this topic is fundamental for students and educators in making calculations, so it is the first step that should be implemented in the process of teaching and learning mathematics.

Fractions were also a favorite topic in the algebra and arithmetic textbooks that the some researchers investigated. Mathematics textbooks are often blamed for the misunderstandings students have about fractions (Behr et al., 1992). For example, some has pointed to deficiencies in "problem situations that provide experiences with composition, decomposition, and con- 
ceptual portion units" and a "lack of experience with qualitative reasoning about fraction size, order relation, and the out come of operations". Bezuk and Cramer (1989) noted that fractions $\mid \begin{aligned} & \text { PROBLEMS } \\ & \text { OF EDUCATION } \\ & \text { IN THE 21 } 1^{\text {st }} \text { CENTURY } \\ & \text { Vol. 75, No. 3, } 2017\end{aligned}$ are frequently found as topics of the textbooks used in elementary schools. This topic is often introduced early in the second grade, with the names and types of different fractions being covered, but the methods for calculation and the presentation of fractions vary depending on each mathematics textbook and the different countries in which they are used. In contrast, the topic of geometry and data analysis was not found to be considered by many of the selected studies, but this may have been because this topic is taught at the high school level, such that the researchers may have assumed that the students are typically already able to analyze these topics.

\section{Levels in School}

The 44 studies reviewed in this study analyzed mathematics textbooks intended for use at various school's level. These levels in school can be categorized into four groups: Kindergarten/primary school, elementary school, junior high school, and senior high school. In the 44 studies, 4 considered textbooks used at the kindergarten/primary school level, 19 considered textbooks used at the elementary school level, 17 considered textbooks used at the junior high school level, 2 considered textbooks used at the senior high school level, and 2 did not fit any of these specific levels. More specifically, those last 2 studies considered education as a whole and did not focus on a specific level of education.

The researchers analyzed the textbooks in terms of curriculum and pedagogy. In this study, however, no past analysis of mathematics textbooks at the university level could be found, possibly because of various factors, such as the possibility that mathematics textbooks used at the university level are compiled by professional educators who make exact considerations regarding the development of the critical thinking skills of students

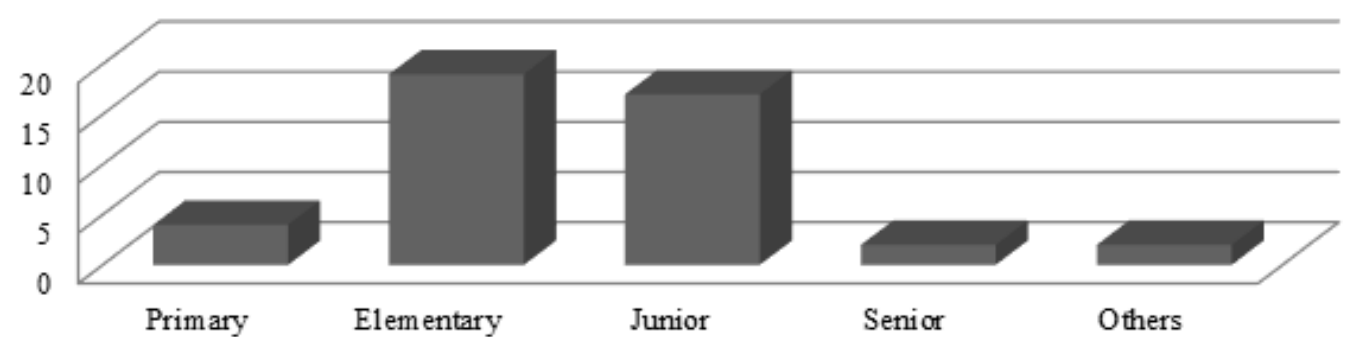

Figure 3: Dispersion levels in school from primary until senior high school.

The results in Figure 3, authors found that textbooks used at the elementary and junior high school levels were those most commonly investigated by the studies. In contrast, authors found only one study that looked at textbooks used at the senior high school level.

\section{Discussion}

In this research, authors identified total of 44 past studies that engaged in the analysis of mathematics textbooks. Authors further characterized these studies in terms of specific characteristics: 1 .The perspective on learning in mathematics textbooks, 2 . The subjects are taught in mathematics textbook, and 3. Level of school that was used mathematic textbooks. 
Cheng Chieh CHANG, Sari Muthia SILALAHI. A review and content analysis of mathematics textbooks in educational research

PROBLEMS

OF EDUCATION

IN THE $21^{\text {st }}$ CENTURY

Vol. 75 , No. 3,2017

Table 2. Relationship between perspectives on learning with the subject in analysis of mathematics textbooks.

\begin{tabular}{llllllll}
\hline $\begin{array}{l}\text { Codel } \\
\text { Subject }\end{array}$ & $\begin{array}{l}\text { Number and } \\
\text { Operation }\end{array}$ & $\begin{array}{l}\text { Arithmetic and } \\
\text { Algebra }\end{array}$ & Geometry & Measurement & Data Analysis & Other & Total \\
\hline PS & 3 & 1 & 0 & 1 & 0 & 1 & 6 \\
RS & 1 & 0 & 1 & 0 & 0 & 1 & 3 \\
CM & 0 & 0 & 0 & 0 & 0 & 0 & 0 \\
CN & 1 & 0 & 0 & 0 & 0 & 0 & 1 \\
RP & 1 & 0 & 0 & 0 & 0 & 1 & 2 \\
ID & 0 & 0 & 0 & 0 & 1 & 2 & 3 \\
IT & 0 & 0 & 0 & 0 & 0 & 0 & 0 \\
TF & 0 & 0 & 0 & 0 & 0 & 1 & 1 \\
MF & 3 & 5 & 1 & 0 & 1 & 0 & 10 \\
CF & 0 & 0 & 0 & 0 & 0 & 0 & 0 \\
PR & 1 & 1 & 0 & 2 & 0 & 1 & 5 \\
Other & 4 & 1 & 0 & 1 & 0 & 7 & 13 \\
Total & 14 & 8 & 2 & 4 & 2 & 14 & 44 \\
\hline
\end{tabular}

Table. 2 shows that number and operation which is the most widely analyzed by researchers in mathematics textbooks. They focused on integer operations (addition and subtraction). Some of researchers explained it was a basic knowledge for the textbook's purpose to introduce the problems especially related to perspective on learning students (Jitendra \& Buchman 2005). PS, MF and Others in number and operation subject got the high result, it's mean in number and operation three part of them have important thing for contributed to students achievement such as encourage and challenge student to solve the problems, gave the student opportunities for explained their idea with single step or multi-step. That were the reasons for some researchers have chosen them in number and operation. Meanwhile, geometry got the small frequencies. Due to the limitations in problems represented on textbooks about it. The other reasons, it was introduced at the higher secondary level (Junior High school).

Table 3. Relationship between perspectives on learning with school's level in analysis of mathematics textbooks.

\begin{tabular}{lllllll}
\hline $\begin{array}{l}\text { Code/ School's } \\
\text { Level }\end{array}$ & $\begin{array}{l}\text { Primary } \\
\text { School }\end{array}$ & $\begin{array}{l}\text { Elementary } \\
\text { School }\end{array}$ & Junior High School & Senior High School & Other & Total \\
\hline PS & 0 & 3 & 2 & 1 & 0 & 6 \\
RS & 0 & 1 & 2 & 0 & 0 & 3 \\
CM & 0 & 0 & 0 & 0 & 0 & 0 \\
CN & 1 & 0 & 0 & 0 & 0 & 1 \\
RP & 0 & 0 & 2 & 0 & 0 & 2 \\
ID & 0 & 0 & 3 & 1 & 0 & 4 \\
IT & 0 & 0 & 0 & 0 & 0 & 0 \\
TF & 0 & 0 & 1 & 0 & 0 & 1 \\
MF & 2 & 7 & 0 & 0 & 1 & 10 \\
CF & 0 & 0 & 0 & 0 & 0 & 0 \\
PR & 0 & 1 & 4 & 0 & 0 & 5 \\
Other & 1 & 7 & 3 & 0 & 1 & 12 \\
Total & 4 & 19 & 17 & 2 & 2 & 44 \\
\hline
\end{tabular}




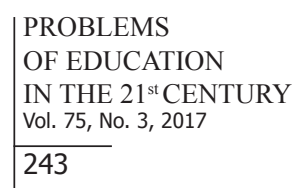
which is elementary school and junior high school more got pay attention by researcher. In elementary school, fifth grade was chosen more than the others grades. Authors may have thought because the fifth grade is an important time for students to cement the skills they have gained throughout the upper grades as well as develop them even further in preparation for middle school. Fifth grade is about helping students to practice, refine and grow their skills, taking all that they have learned to the next step. Fifth graders build on what they learn in 4th grade by thinking and analyzing in deeper ways about what they learn and read, writing structure, and clear and detailed pieces where the student was ready. It was be similar to Abed \& Asbi, (2015) have explained that analysis mathematics textbooks in early stage by using students' textbooks was an important issue to understand the basic started from elementary education. MF became the focus some researchers in elementary school. Authors examined because MF described about task and question which represented on textbook to develop student thinking and understanding.

In junior high school, Eighth grade became the most attention by some researcher because it allows students to mature, become better students and prepare for high school. It was be consistent with Ding and Li, (2010) described eighth grade really appropriated to build students thinking through the textbooks. Different from MF which became focus in elementary school, PR became the majority in junior high which talked about how student made response type and measure their cognitive requirement. Authors believe PR could be gave some potentially such as student will learn a number of skills and ideas that he or she must know and understand to be ready for college and career. Student will continue to learn how to write and reason with algebraic expressions. Students also will make a thorough study of linear equations with one and two variables.

Contradict with senior high school which got the small result. It was because authors believed at the time student have been learn and study to mature, become better students and they only focus prepare going to university, it was meant they have prepared and studied in junior high school when teacher thought them in classroom.

Same results in perspective on learning related to subject and school's level. Mathematics feature has got the greater result than the others. Authors identified the important scaffolding could facilitate student understanding and skill acquisition. A task's cognitive complexity could determine the possibilities for student engagement in cognitively challenging tasks during instruction (Charalambous, et al., 2010); when students explained and justified their answers, reviews their understanding of mathematics is reinforced (NCTM, 2000). This research can contribute for the next researcher to do analysis in all of subjects. 
Cheng Chieh CHANG, Sari Muthia SILALAHI. A review and content analysis of mathematics textbooks in educational research

PROBLEMS

OF EDUCATION

IN THE $21^{\text {st }}$ CENTURY Vol. 75, No. 3, 2017

Table 4. Relationship between perspectives on learning with years in analysis of mathematics textbooks.

\begin{tabular}{llllll}
\hline Code & $1953-2000$ & $\mathbf{2 0 0 1 - 2 0 0 5}$ & $\mathbf{2 0 0 6 - 2 0 1 0}$ & $\mathbf{2 0 1 1 - 2 0 1 5}$ & Total \\
\hline PS & 3 & 1 & 2 & 0 & 6 \\
RS & 0 & 1 & 2 & 0 & 3 \\
CM & 0 & 0 & 0 & 0 & 0 \\
CN & 1 & 0 & 0 & 0 & 1 \\
RP & 1 & 0 & 1 & 0 & 2 \\
ID & 1 & 0 & 1 & 1 & 3 \\
IT & 0 & 0 & 0 & 0 & 0 \\
TF & 1 & 0 & 0 & 0 & 1 \\
MF & 2 & 1 & 4 & 4 & 11 \\
CF & 0 & 0 & 0 & 0 & 0 \\
PR & 0 & 1 & 1 & 3 & 5 \\
Other & 3 & 5 & 3 & 1 & 12 \\
Total & 12 & 9 & 14 & 9 & 44 \\
\hline
\end{tabular}

Table 4 is the extra information that have prepared to identify which have been undertaken in research filed, thus have instability performed in area analysis of mathematics textbooks. 1953 - 2000 found 12 papers but in 2001- 2005 decrease to 9 papers but after the following year, there were number of paper increase until 14 papers. Viewing from the perspective on learning and different years, they have same results indicated mathematics feature also getting more paid attention from researchers. The second is others which also part of perspective in learning in every year have contributed for making research. It related to the application mathematics in students life, application mathematics in teaching and learning. It is also important part for the implementation in education system which is conducting now, this is the reason that researchers conducted in annual analyze.

\section{Conclusions and Suggestions}

This review offers three contributions. First, we summarized the selected past research articles in terms perspective on learning, finding that the distributive property and analysis of standards received the most attention from researchers. The focus of discussion was widely on the analysis in each criterias. From analysis in past papers regarding the mathematics textbook from 44 papers which become focused attention by these studies are: 1 . In subject: Number and operation, 2. In school's level: Elementary school, 3. Year: 2006 - 2010. On the other hand, if we see perspective on learning how it contibuted, we found that MF got high attenntion in every part distribution from three aspects include subject, school's level and years. Researchers believed that MF examine student's knowledge and skill how to solve problems with different answer in single and multi-step using their experiences and understanding.

Eventhough, we also found CM, IT, and CF didn't have result in these studies, if we looked from paper explanation, IT examines the social and personal relationship between author and others. We found, it was not related with student's need or teacher's need. So, no studies used it. CM and CF talked about comunication and contextual feature, researchers explained that it was proper to high school or universities. Authors also can glean insights that can help us understand about part of each perspective learning can contibute for teacher which one 
is the most analisis by researcher and lack. So teacher can identify where is the proper for the student. These insights can be used by teachers and researchers in future to support students' mathematical learning.

The second contribution of this study was its focus on the subjects taught by the textbooks analyzed by the past studies. In this regard, we found that the subject of number and operations received the most attention. This subject is important because this topic involves a basic introduction to calculations for students, and this is likely thereason why the researchers chose to analyze this topic more frequently. The third contribution of this study was its focus onthe level in school in which the textbooks investigated by the past studies used. In this regard, we found that elementary school mathematics textbooks were the most frequent target of investigation. Textbooks at the elementary level selected for analysis most frequently because this level is the first level of school at which a child starts learning and understanding numeracy and how to think mathematically.

In the future, it is expected that further research can be conducted in different fields, and also that deeper analyses can continue to explore the correlations between various perspective on learning and school levels (primary level, senior high school level, and university level). We expect that in the following years there will be alot of research regarding the analysis of mathematics textbooks that will help teachers, educators, and even the government to better develop students' mathematics textbooks so that they are more efficient, convenient, and useful.

Finally, we call for attention to the relevant theoretical issues in future studies. In addition, as suggested previously, since interdisciplinary and collaborative studies are needed in the future, whether there is a coherent theoretical framework and coding table that can guide all such research should be explored. Analyses of the theoretical and add more perspective on learning issues will help educational researchers to appropriately apply the eye tracking methods in their studies. It is hoped that such a review of the theoretical bases will appear in the near future.

\section{References}

Abed, E. R., \& Al-Absi, M. (2015). Content analysis of Jordanian elementary textbooks during. International Education Studies, 8 (3), 159-166

Baker, D., Knipe, H., Collins, J., Leon, J., Cummings, E., Blair, C., \& Gamson, D. (2010). Content analysis and cognitive assessment of textbooks from 1900 to 2000. Journal for Research in Mathematics Education, 41 (4), 383-423.

Ball, D. L., \& Bass, H. (2000). Interweaving content and pedagogy in teaching and learning to teach: Knowing and using mathematics. In J. Boaler (Ed.), Multiple perspectives a mathematics teaching and learning (pp. 83 - 104). Westport, CT: Ablex Publishing.

Behr, M. J., Harel, G., Post, T., \& Lesh, R. (1992). Rational number, ration, proportion. In D. A. Grouws (Ed.), Handbook of research on mathematics teaching and learning (pp. 296-333). NewYork: Macmillan.

Berelson, B. (1952). Content analysis in communication research. New York, NY: Free Press.

Bezuk, N., \& Cramer, K. (1989). Teaching about fractions: What when and how? In P. Trafton (Ed.), New directions for elementary school mathematics: 1989 Yearbook (pp. 156-167). Reston: National Council of Teachers of Mathematics.

Birgit, P., Linda, H., \& Milton, K. (2001). Mathematics textbooks and their use in English, French, and German classrooms: A way to understand teaching and learning cultures. Zentrallattfür Didaktik der Mathematik, 33 (5), 158-175.

Burch, R. L. (1953). Formal analysis as a problem-solving procedure. The Journal of Education, 136 (2), 44-47.

Cabassut, R. (2005), Argumentation and proof in examples taken from French and German textbooks. In M. Bosch (Ed.), Proceedings of the Fourth Congress of the European Society for Research in Mathematics Education, (pp. 391-400), Spain: ERME. 
Cheng Chieh CHANG, Sari Muthia SILALAHI. A review and content analysis of mathematics textbooks in educational research

PROBLEMS

OF EDUCATION

IN THE $21^{\text {st }}$ CENTURY Vol. 75, No. 3, 2017

246
Carnine, D., Jitendra, A. K., \& Silbert, J. (1997). A descriptive analysis of mathematics curricula materials from a pedagogical perspective: A case study of fractions. Remedial and Special Education, $18,66-81$.

Charalambous, Y., Delaney, S., Hsu, H., \& Vilma (2010). A comparative analysis of the addition and subtraction of fractions in textbooks from three countries. Mathematical Thinking and Learning, $12,117-151$.

Ding, M., \& Li, X. (2010). A comparative analysis of the distributive property in U.S. and Chinese elementary mathematics textbooks. Cognition and Instruction, 28 (2), 146-180.

Eisenmann, H. A. B. (2007). From intended curriculum to written curriculum: Examining the "voice" of a mathematics textbook. Journal for Research in Mathematics Education, 38 (40), 344-369.

Eren, R., (2014). A comparative analysis of questions in American, Singaporean, and Turkish mathematics textbooks based on the topics covered in 8th grade in turkey. Educational Sciences: Theory \& Practice, 14 (1), 411-421.

Flanders, J. (1987). How much of the content in mathematics textbooks is new? The Arithmetic Teacher, 35 (1), 18-23.

Fujita, T., \& Jones K. (2002). Opportunities for the development of geometrical reasoning in current textbooks in the U.K and Japan. Proceedings of the British Society for Research into Learning Mathematics, 22 (3), 79-84.

Fuson, K., Stigler, J. W., \& Bartsch, K. (1988). Grade placement of addition and subtraction topics in Japan, mainland China, the Soviet Union, Taiwan, and the United States. Journal for Research in Mathematics Education, 19 (5), 449-456.

Garderen, D., Scheuermann, A., \& Jackson, A. (2012). Developing representational ability in mathematics for students with learning disabilities: A content analysis of grades 6 and 7 textbooks. Learning Disability Quarterly, 35 (1), 24-38.

Gerofsky, S. (1999). Genre analysis as a way of understanding pedagogy in mathematics education. For the Learning of Mathematics, 19 (3), 36-46.

Halim, A. (2006). A comparative study of mathematics curriculum at primary level in Bangladesh and India (West Bengal). Bangladesh Education Journal A Half-Yearly Publication of UNESCO-Based Researchers' Forum, 5 (1), 41-51.

Halliday, M. (1973). Explorations in the functions of language. London: Edward Arnold.

Howson, G. (1996). Mathematics textbooks: A comparative study of grade 8 texts. The Mathematics Teacher, 89 (3), 258.

Hussain, A. (2012). How do elementary textbooks address fractions? A review of mathematics textbooks in the Usa, Japan, and Kuwait. Educational Studies in Mathematics, 79, 239-261.

Jitendra, A. K., \& Buchman (2005). A comparative analysis of third-grade mathematics textbooks before and after 2000. NCTM Standards, Assessment for Effective International, 30 (2), 47-62.

Jitendra, A. K., et al. (2005). Adherence to mathematics professional standards and instructional design criteria for problem-solving in mathematics. Council for Exceptional Children, 71 (3), 319-337.

Jones, D. L., et al., (2015). The statistical content of elementary school mathematics textbooks. Journal of Statistics Education, 23 (3), 1-18.

Jones, K., \& Fujita, T., (2002). British society for research into learning mathematics geometry working group. In Fujita, T., and Jones, K., (2002). Opportunities for the development of geometrical reasoning in current textbooks in the UK and Japan. Proceedings of the British Society for Research into Learning Mathematics, 22 (3), 79-84.

Kane, R. B. (1970). The readability of mathematics textbooks revisited. The Mathematics Teacher, 63 (7), 579-581.

Kilpatric, J., \& Swafford, J. (2002). Helping children learn mathematics. Washington, DC: National Academy Press.

Kilpatrick, J., \& Swafford, J., \& Findell, B. (2001). Adding it up: Helping children learn mathematics. Washington, D.C.: National Academy Press

Kiulik, S., \& Rudnick, J. A. (1987). Problem solving: A handbook for teachers (2nd ed.). Boston: Allyn and Bacon. 
Kyungmee, P., \& Frederick, L. K. S. (2006). A comparative study of the mathematics textbooks of China, England, Japan, Korea, and the United States. Mathematics Education in Different Cultural Traditions A Comparative Study of East Asia and the West, 9, 227-238.

Lappan, G. (1999). Revitalizing and refocusing our efforts. Journal for Research in Mathematics Education, 30, 568-578.

Li, Y. (2000). A comparison of problems that follow selected content presentations in American and Chinese mathematics textbooks. Journal for Research in Mathematics Education, 31 (2), 234-241.

Li, Y. (2007a). Curriculum research to improve teaching and learning. School Science and Mathematics, 107, 166-168.

Li, Y. (2008). Transforming curriculum from intended to implemented: What teachers need to do and what they learned in the United States and China. In Z. Usiskin \& E.Willmore (Eds.), Mathematics curriculum in Pacific Rim countries-China, Japan, Korea, and Singapore (pp. 183-195). Charlotte, NC: Information Age.

Li, Y., \& Kulm, G. (2008). Knowledge and confidence of preservice mathematics teacher: The case of fraction division. ZDM-The International Journal on Mathematics Education, 40, 833-843.

Li, Y., Chen, X., \& An, S. (2009). Conceptualizing and organizing content for teaching and learning in selected Chinese, Japanese and US mathematics textbooks: The case of fraction division. ZDM Mathematics Education, 41, $809-826$.

Lianghuo, F., \& Yan, Z. (2000). Problem solving in Singapore secondary mathematics textbooks. The Mathematics Educator, 5 (1/2), 117-141.

Lianghuo, F., \& Yan, Z. (2007). Representation of problem-solving procedures: A comparative look at China, Singapore, and US mathematics textbooks. Educational Studies in Mathematics, 66 (1), $61-75$.

Linda, H., \& Birgit, P. (2002). An investigation of mathematics textbooks and their use in English, French and German classroom: Who gets an opportunity to learn what? British Educational Research Journal, 28 (4), 567-590.

Maggie, M. B. (1994). The theme of individualism in mathematics education: An examination of mathematics textbooks. For The Learning of Mathematics, 14 (3), 36-42.

Mayer, R. E., Sims, V., \& Hidet T., (1995). A comparison of how textbooks teach mathematical problem solving in Japan and the United States. American Educational Research Journal, 32 (2), 443-460.

National Council of Teachers of Mathematics. (1989). Curriculum and evaluation standards for school mathematics. Reston, VA: Author.

National Mathematics Advisory Panel (2008). Foundations for success: The final report of the national mathematics advisory panel. Washington, DC: U.S. Department of Education.

O'keeffe, L., \& O'donoghue, J. (2015). A role for language analysis in mathematics textbook analysis. International Journal of Science and Mathematics Education, 13 (3), 605-630.

Özgeldia, M., \& Esen, Y. (2010). Analysis of mathematical tasks in Turkish elementary school mathematics textbooks. Procedia Social and Behavioral Sciences, 2, 2277-2281.

Reys, B., Robert, E., \& Masataka, K. (1996). The development of computation in three Japanese primarygrade textbooks. The Elementary School Journal, 96 (4), 423-437.

Seán, D., Charalambos, Y. C., Hui, Y. H., \& Vilma, M. (2007). The treatment of addition and subtraction of fractions in Cypriot, Irish, and Taiwanese textbooks. In Woo, Jeong-Ho, et al., (Ed.), International group for the psychology of mathematics education: Proceedings of the 31st Conference of the International Group for the Psychology of Mathematics Education, 2, 193-208. Korea: The Korea Society of Educational Studies in Mathematics.

Shulman, L. S. (1986b). Those who understand: Knowledge growth in teaching. Educational Research, 15 (2), 4-14.

Smith, F. (1969). The readability of junior high school mathematics textbooks. The Mathematics Teacher, 62 (4), 289-291.

Son, J. (2005). A comparison of how textbooks teach multiplication of fractions and division of fractions in Korea and in the U.S. In Chick, H. L., \& Vincent, J. L. (Eds.), Learners and learning environments: Proceedings of the 29th Annual Conference of the International Group for the Psychology of Mathematics Education, (pp. 201-208). Melbourne: PME. ISSN 0771-100X.

PROBLEMS

OF EDUCATION

IN THE $21^{\text {st }}$ CENTURY

Vol. 75, No. 3, 2017 
Cheng Chieh CHANG, Sari Muthia SILALAHI. A review and content analysis of mathematics textbooks in educational research

PROBLEMS

OF EDUCATION

IN THE $21^{\text {st }}$ CENTURY Vol. 75, No. 3, 2017

Sood, S., \& Jitendra, A. K. (2007). A comparative analysis of number sense instruction in reform-based and traditional mathematics textbooks. The Journal Of Special Education, 41 (3), 145-157.

Stacey, K., \& Vincent, J. (2009). Modes of reasoning in explanations in Australian eighth-grade mathematics textbooks. Educational Studies in Mathematics, 72, 271-288.

Stigler, J., Fuson, C., Ham, M., \& Kim, M.S. (1986). An analysis of addition and subtraction word problems in American and Soviet elementary mathematics textbooks. Cognition and Instruction, 3 (3), 153-171.

Sun, X. (2011). Variation problems and their roles in the topic of fraction division in Chinese mathematics textbook examples. Educational Studies in Mathematics, 76 (1), 65-85.

Sutherland, R., Winter, J., \& Harries, T. (2001). A transnational comparison of primary mathematics textbooks: The case of multiplication. Research in Mathematics Education, 3 (1), 155-167.

Suttharat, \& Maitree (2013). The textbook analysis on multiplication: The case of Japan, Singapore, and Thailand. Creative Education, 4 (4), 259-262.

Verschaffel, L., \& De Corte, E. (1996). Number and arithmetic. In A. Bishop, K. Clements, C. Keitel, J. Kilpatrick, \& C. Laborde (Eds.), International handbook of mathematics education (pp. 99-137). Dordrecht, The Netherlands: Kluwer Academic Publishers.

Wijaya, A., Panhuizen, M., \& Doorman, M. (2015). Opportunity-to-learncontext-based tasks provided by mathematics textbooks. Educational Studies in Mathematics, 89 (1), 41-65.

Xin, Y. P., (2007). Word problem solving tasks in textbooks and their relation to student performance. The Journal of Educational Research, 100 (6), 347-360.

Yeap, B., Beverly, F., Jack (2006). Comparative study of arithmetic problems in Singaporean and American mathematics textbooks. Mathematics Education in Different Cultural Traditions-A Comparative Study of East Asia and the West, 9, 213-225.

Appendix. Analysis of the mathematics textbooks investigated in each reviewed study.

\begin{tabular}{|c|c|c|c|c|c|}
\hline No & Authors & Title & Level & $\begin{array}{l}\text { Focus On } \\
\text { Learning }\end{array}$ & $\begin{array}{l}\text { Material/Sub- } \\
\text { ject }\end{array}$ \\
\hline 1. & $\begin{array}{l}\text { Sood \& Jitendra } \\
(2007)\end{array}$ & $\begin{array}{l}\text { A Comparative Analysis of Number Sense } \\
\text { Instruction in Reform-Based and Traditional } \\
\text { Mathematics Textbooks }\end{array}$ & $\begin{array}{l}\text { Elementary } \\
\text { School }\end{array}$ & $\begin{array}{l}\text { Evaluating } \\
\text { Number Sense } \\
\text { Content }\end{array}$ & $\begin{array}{l}\text { Number sense } \\
\text { (Others) }\end{array}$ \\
\hline 2. & Eren ( 2014) & $\begin{array}{l}\text { A Comparative Analysis of Questions in } \\
\text { American, Singaporean, and Turkish Math- } \\
\text { ematics Textbooks Based on the Topics } \\
\text { Covered in 8th Grade in Turkey }\end{array}$ & $\begin{array}{l}\text { Junior High } \\
\text { School }\end{array}$ & Questions & $\begin{array}{l}\text { Number } \\
\text { Geometry } \\
\text { Algebra } \\
\text { Statistic }\end{array}$ \\
\hline 3. & $\begin{array}{l}\text { Charalambous, } \\
\text { Delaney, Hsu \& } \\
\text { Vilma ( 2010) }\end{array}$ & $\begin{array}{l}\text { A Comparative Analysis of the Addition and } \\
\text { Subtraction of Fractions in Textbooks from } \\
\text { Three Countries }\end{array}$ & $\begin{array}{l}\text { Primary } \\
\text { School }\end{array}$ & $\begin{array}{l}\text { Concepts } \\
\text { in Structure } \\
\text { textbook }\end{array}$ & Factions \\
\hline 4. & Ding \& Li ( 2010) & $\begin{array}{l}\text { A Comparative Analysis of the Distributive } \\
\text { Property in U.S. and Chinese Elementary } \\
\text { Mathematics Textbooks }\end{array}$ & $\begin{array}{l}\text { Elementary } \\
\text { School }\end{array}$ & $\begin{array}{l}\text { Problem con- } \\
\text { texts }\end{array}$ & $\begin{array}{l}\text { Multiplication } \\
\text { problems }\end{array}$ \\
\hline 5. & $\begin{array}{l}\text { Jitendra \& Buch- } \\
\text { man (2005) }\end{array}$ & $\begin{array}{l}\text { A Comparative Analysis of Third-Grade } \\
\text { Mathematics Textbooks Before and After the } \\
2000 \text { NCTM Standards. }\end{array}$ & $\begin{array}{l}\text { Elementary } \\
\text { School }\end{array}$ & $\begin{array}{l}\text { Analysis Stand- } \\
\text { ards }\end{array}$ & $\begin{array}{l}\text { Addition and } \\
\text { Subtraction }\end{array}$ \\
\hline 6. & Halim (2006) & $\begin{array}{l}\text { A Comparative Study Of Mathematics Cur- } \\
\text { riculum At Primary Level In Bangladesh and } \\
\text { India (West Bengal) }\end{array}$ & $\begin{array}{l}\text { Primary } \\
\text { School }\end{array}$ & $\begin{array}{l}\text { Critical } \\
\text { Examination } \\
\text { and Analysis } \\
\text { Of Curriculum } \\
\text { Objectives }\end{array}$ & Content-Areas \\
\hline
\end{tabular}




\begin{tabular}{|c|c|c|c|c|c|c|}
\hline 7. & $\begin{array}{l}\text { Kyungmee \& } \\
\text { Frederick (2006) }\end{array}$ & $\begin{array}{l}\text { A Comparative Study Of The Mathemat- } \\
\text { ics Textbooks Of China, England, Japan, } \\
\text { Korea, and The United States. }\end{array}$ & $\begin{array}{l}\text { Junior High } \\
\text { School }\end{array}$ & $\begin{array}{l}\text { Mathematics } \\
\text { education }\end{array}$ & $\begin{array}{l}\text { All the Struc- } \\
\text { ture } \\
\text { ( Other) }\end{array}$ & 249 \\
\hline 8. & $\operatorname{LiY}(2000)$ & $\begin{array}{l}\text { A Comparison of Problems That Follow } \\
\text { Selected Content Presentations in American } \\
\text { and Chinese Mathematics Textbooks. }\end{array}$ & $\begin{array}{l}\text { Junior High } \\
\text { School }\end{array}$ & $\begin{array}{l}\text { Mathematical } \\
\text { problems }\end{array}$ & $\begin{array}{l}\text { Integer opera- } \\
\text { tions }\end{array}$ & \\
\hline 9. & $\begin{array}{l}\text { Valerie \& Hidet } \\
\text { (1995) }\end{array}$ & $\begin{array}{l}\text { A Comparison of How Textbooks Teach } \\
\text { Mathematical Problem Solving in Japan and } \\
\text { the United States. }\end{array}$ & $\begin{array}{l}\text { Junior High } \\
\text { School }\end{array}$ & Problem-solving & $\begin{array}{l}\text { Positive and } \\
\text { Negative Num- } \\
\text { bers }\end{array}$ & \\
\hline 10. & Son (2005) & $\begin{array}{l}\text { A Comparison Of How Textbooks Teach } \\
\text { Multiplication Of Fractions and Division Of } \\
\text { Fractions In Korea And In The U.S. }\end{array}$ & $\begin{array}{l}\text { Elementary } \\
\text { School }\end{array}$ & $\begin{array}{l}\text { Content and } \\
\text { Problem } \\
\text { Analysis }\end{array}$ & Fractions. & \\
\hline
\end{tabular}

\begin{tabular}{|c|c|c|c|}
\hline $\begin{array}{l}\text { Baker \& Knipe } \\
\text { (2010) }\end{array}$ & $\begin{array}{l}\text { A Content Analysis and Cognitive Assess- } \\
\text { ment of Textbooks From } 1900 \text { to } 2000\end{array}$ & $\begin{array}{l}\text { Elementary } \\
\text { School }\end{array}$ & $\begin{array}{l}\text { A Content Analy- } \\
\text { sis and cognitive Over All } \\
\text { assessment }\end{array}$ \\
\hline
\end{tabular}

\begin{tabular}{|c|c|c|c|c|c|}
\hline 12. & $\begin{array}{l}\text { O'keeffe \& } \\
\text { O'donoghue } \\
\text { (2015) }\end{array}$ & $\begin{array}{l}\text { A Role For Language Analysis In Mathemat- } \\
\text { ics Textbook Analysis }\end{array}$ & $\begin{array}{l}\text { Junior } \\
\text { Secondary } \\
\text { school }\end{array}$ & $\begin{array}{l}\text { Role of Lan- } \\
\text { guage }\end{array}$ & $\begin{array}{l}\text { Over All } \\
\text { ( Other ) }\end{array}$ \\
\hline 13. & $\begin{array}{l}\text { Sutherland, } \\
\text { Winter \& Harries } \\
\text { (2001) }\end{array}$ & $\begin{array}{l}\text { A Transnational Comparison Of Primary } \\
\text { Mathematics Textbooks : The Case Of } \\
\text { Multiplication }\end{array}$ & $\begin{array}{l}\text { Primary } \\
\text { School }\end{array}$ & $\begin{array}{l}\text { The Nature of } \\
\text { the Images and }\end{array}$ & Multiplication \\
\hline 14. & $\begin{array}{l}\text { Jitendra, et al. } \\
\text { (2005) }\end{array}$ & $\begin{array}{l}\text { Adherence to Mathematics Professional } \\
\text { Standards and Instructional Design Criteria } \\
\text { for Problem-Solving in Mathematics }\end{array}$ & $\begin{array}{l}\text { Elementary } \\
\text { School }\end{array}$ & $\begin{array}{l}\text { The Standards } \\
\text { across }\end{array}$ & $\begin{array}{l}\text { Addition and } \\
\text { Subtraction }\end{array}$ \\
\hline 15. & $\begin{array}{l}\text { Stigler, Fuson, } \\
\text { Ham, \& Kim } \\
(1986)\end{array}$ & $\begin{array}{l}\text { An Analysis of Addition and Subtraction } \\
\text { Word Problems in American and Soviet } \\
\text { Elementary Mathematics Textbooks }\end{array}$ & $\begin{array}{l}\text { Elementary } \\
\text { School }\end{array}$ & Word problems & $\begin{array}{l}\text { Addition and } \\
\text { Subtraction }\end{array}$ \\
\hline 16. & $\begin{array}{l}\text { Linda \& Birgit } \\
\text { (2002) }\end{array}$ & $\begin{array}{l}\text { An Investigation of Mathematics Textbooks } \\
\text { and Their Use in English, French and Ger- } \\
\text { man Classroom: who gets an opportunity to } \\
\text { learn what? }\end{array}$ & $\begin{array}{l}\text { Junior High } \\
\text { School }\end{array}$ & $\begin{array}{l}\text { Contexts, and of } \\
\text { the Pedagogi- } \\
\text { cal ' }\end{array}$ & Numbers \\
\hline 17. & $\begin{array}{l}\text { Özgeldia \& Esen } \\
(2010)\end{array}$ & $\begin{array}{l}\text { Analysis of mathematical tasks in Turkish } \\
\text { elementary school mathematics textbooks }\end{array}$ & $\begin{array}{l}\text { Junior High } \\
\text { School }\end{array}$ & Tasks & Over All \\
\hline 18. & Cabassut (2005) & $\begin{array}{l}\text { Argumentation and Proof In Examples } \\
\text { Taken From French And German Textbooks }\end{array}$ & $\begin{array}{l}\text { Junior High } \\
\text { School }\end{array}$ & $\begin{array}{l}\text { Arguments of } \\
\text { plausibility and } \\
\text { arguments of } \\
\text { necessity }\end{array}$ & $\begin{array}{l}\text { Pythagoras's } \\
\text { theorem }\end{array}$ \\
\hline 19. & $\begin{array}{l}\text { Yeap, Beverly, \& } \\
\text { Jack (2006) }\end{array}$ & $\begin{array}{l}\text { Comparative Study Of Arithmetic Problems } \\
\text { In Singaporean And American Mathematics } \\
\text { Textbooks }\end{array}$ & $\begin{array}{l}\text { Elementary } \\
\text { School }\end{array}$ & Problem-solving & Over All \\
\hline 20. & $\begin{array}{l}\text { Li, Chen, \& An } \\
\text { (2009) }\end{array}$ & $\begin{array}{l}\text { Conceptualizing and organizing content for } \\
\text { teaching and learning in selected Chinese, } \\
\text { Japanese and US mathematics textbooks: } \\
\text { the case of fraction division }\end{array}$ & $\begin{array}{l}\text { Elementary } \\
\text { School }\end{array}$ & Content & Fraction \\
\hline
\end{tabular}


Cheng Chieh CHANG, Sari Muthia SILALAHI. A review and content analysis of mathematics textbooks in educational research

PROBLEMS

OF EDUCATION

IN THE $21^{\text {st }}$ CENTURY Vol. 75 , No. 3, 2017

21

Abed \& Al-Absi Content Analysis of Jordanian Elementary Elementary

(2015) Textbooks during 1970-2013 as Case Study School

Numbers and

operations,

$\begin{array}{ll}\text { algebra, } & \\ \text { ability. } & \end{array}$

\begin{tabular}{|c|c|c|c|c|c|}
\hline 22. & $\begin{array}{l}\text { Garderen, } \\
\text { Scheuermann \& } \\
\text { Jackson (2012) }\end{array}$ & $\begin{array}{l}\text { Developing Representational Ability in } \\
\text { Mathematics for Students With Learning } \\
\text { Disabilities: A Content Analysis of Grades } 6 \\
\text { and } 7 \text { Textbooks. }\end{array}$ & $\begin{array}{l}\text { Elementary } \\
\text { School }\end{array}$ & $\begin{array}{l}\text { Concrete and } \\
\text { visually based. }\end{array}$ & $\begin{array}{l}\text { Number and } \\
\text { Operations } \\
\text { Algebra and } \\
\text { Geometry. }\end{array}$ \\
\hline 23. & Burch (1953) & $\begin{array}{l}\text { Formal Analysis As A Problem-Solving } \\
\text { Procedure. }\end{array}$ & $\begin{array}{l}\text { Elementary } \\
\text { School }\end{array}$ & Problem solving & Algorism \\
\hline 24. & $\begin{array}{l}\text { Beth, Herbel, } \\
\text { Eisenmann (2007) }\end{array}$ & $\begin{array}{l}\text { From Intended Curriculum to Written } \\
\text { Curriculum: Examining the "Voice" of a } \\
\text { Mathematics Textbook. }\end{array}$ & $\begin{array}{l}\text { Junior High } \\
\text { School }\end{array}$ & Voice & Over All \\
\hline 25. & Gerofsky (1999) & $\begin{array}{l}\text { Genre Analysis as a Way of Understanding } \\
\text { Pedagogy in Mathematics Education }\end{array}$ & Other & Word problems & Over All \\
\hline 26. & $\begin{array}{l}\text { Fuson, Stigler \& } \\
\text { Bartsch (1988) }\end{array}$ & $\begin{array}{l}\text { Grade Placement of Addition and Subtrac- } \\
\text { tion Topics in Japan, Mainland China, } \\
\text { the Soviet Union, Taiwan, and the United } \\
\text { States. }\end{array}$ & $\begin{array}{l}\text { Elementary } \\
\text { School }\end{array}$ & Application & $\begin{array}{l}\text { Addition and } \\
\text { Subtraction }\end{array}$ \\
\hline 27. & Alajmi, (2012) & $\begin{array}{l}\text { How do elementary textbooks address frac- } \\
\text { tions? A review of mathematics textbooks in } \\
\text { the USA, Japan, and Kuwait }\end{array}$ & $\begin{array}{l}\text { Elementary } \\
\text { School }\end{array}$ & $\begin{array}{l}\text { 1.The Physical } \\
\text { 2. The Structure } \\
\text { 3. The Nature }\end{array}$ & Fractions \\
\hline 28. & Flanders (1987) & $\begin{array}{l}\text { How Much of the Content in Mathematics } \\
\text { Textbooks Is New? }\end{array}$ & Other & $\begin{array}{l}\text { Content of } \\
\text { textbooks }\end{array}$ & Algebra \\
\hline 29. & Howson (1996) & $\begin{array}{l}\text { Mathematics Textbooks: A Comparative } \\
\text { Study of Grade } 8 \text { Texts }\end{array}$ & $\begin{array}{l}\text { Junior High } \\
\text { School }\end{array}$ & How application & Over All \\
\hline 30. & $\begin{array}{l}\text { Birgit, Linda, \& } \\
\text { Milton (2001) }\end{array}$ & $\begin{array}{l}\text { Mathematics textbooks and their use in } \\
\text { English, French, and German classrooms: } \\
\text { A way to understand teaching and learning } \\
\text { cultures }\end{array}$ & $\begin{array}{l}\text { Junior High } \\
\text { School }\end{array}$ & The pedagogical & Other \\
\hline 31. & $\begin{array}{l}\text { Stacey \& Vincent } \\
(2009)\end{array}$ & $\begin{array}{l}\text { Modes of reasoning in explanations in Aus- } \\
\text { tralian eighth-grade mathematics textbooks }\end{array}$ & $\begin{array}{l}\text { Junior High } \\
\text { School }\end{array}$ & Reasoning & $\begin{array}{l}\text { Number, } \\
\text { Measurement, } \\
\text { Space, and } \\
\text { Algebra } \\
\end{array}$ \\
\hline 32. & $\begin{array}{l}\text { Fujita \& Jones } \\
(2002)\end{array}$ & $\begin{array}{l}\text { Opportunities For The Development Of } \\
\text { Geometrical Reasoning In Current Text- } \\
\text { books In The UK And Japan }\end{array}$ & $\begin{array}{l}\text { Junior High } \\
\text { School }\end{array}$ & Reasoning skills & Geometry \\
\hline 33. & $\begin{array}{l}\text { Wijaya, Panhui- } \\
\text { zen \& Doorman } \\
(2015)\end{array}$ & $\begin{array}{l}\text { Opportunity-to-learn context-based tasks } \\
\text { provided by mathematics textbooks. }\end{array}$ & $\begin{array}{l}\text { Junior High } \\
\text { School }\end{array}$ & $\begin{array}{l}\text { Solving context- } \\
\text { based tasks }\end{array}$ & Measurement \\
\hline 34. & $\begin{array}{l}\text { Lianghuo \& Yan } \\
(2000)\end{array}$ & $\begin{array}{l}\text { Problem Solving In Singaporean Secondary } \\
\text { Mathematics Textbooks }\end{array}$ & $\begin{array}{l}\text { Junior High } \\
\text { School }\end{array}$ & Problem-solving & Algorithms \\
\hline 35. & $\begin{array}{l}\text { Lianghuo \& Yan } \\
(2007)\end{array}$ & $\begin{array}{l}\text { Representation of problem-solving } \\
\text { procedures: A comparative look at China, } \\
\text { Singapore, and US mathematics textbooks }\end{array}$ & $\begin{array}{l}\text { Junior High } \\
\text { School }\end{array}$ & Representation & Over All \\
\hline 36. & $\begin{array}{l}\text { Reys, Robert \& } \\
\text { Masataka (1996) }\end{array}$ & $\begin{array}{l}\text { The Development of Computation in Three } \\
\text { Japanese Primary-Grade Textbooks. }\end{array}$ & $\begin{array}{l}\text { Primary } \\
\text { School }\end{array}$ & Connection & $\begin{array}{l}\text { Addition and } \\
\text { Subtraction }\end{array}$ \\
\hline 37. & Smith (1969) & $\begin{array}{l}\text { The Readability Of Junior High School } \\
\text { Mathematics Textbooks }\end{array}$ & $\begin{array}{l}\text { Junior High } \\
\text { School }\end{array}$ & Content & Over All \\
\hline
\end{tabular}




\begin{tabular}{|c|c|c|c|c|c|c|}
\hline & & & & & & Vol. 75, No. 3, 2017 \\
\hline 38. & Kane (1970) & $\begin{array}{l}\text { The Readability Of Mathematics Textbooks } \\
\text { Revisited }\end{array}$ & Other & $\begin{array}{l}\text { The natural } \\
\text { language }\end{array}$ & Over All & 251 \\
\hline 39. & $\begin{array}{l}\text { Jones, et. al., } \\
(2015)\end{array}$ & $\begin{array}{l}\text { The Statistical Content of Elementary } \\
\text { School Mathematics Textbooks }\end{array}$ & $\begin{array}{l}\text { Elementary } \\
\text { School }\end{array}$ & Task & Statistical & \\
\hline 40. & $\begin{array}{l}\text { Suttharat \& } \\
\text { Maitree (2013) }\end{array}$ & $\begin{array}{l}\text { The Textbook Analysis on Multiplication: The } \\
\text { Case of Japan, Singapore, and Thailand }\end{array}$ & $\begin{array}{l}\text { Elementary } \\
\text { School }\end{array}$ & $\begin{array}{l}\text { The features of } \\
\text { textbooks }\end{array}$ & "Multiplication" & \\
\hline 41. & Maggie (1994) & $\begin{array}{l}\text { The Theme of Individualism in Mathematics } \\
\text { Education: An Examination of Mathematics } \\
\text { Textbooks }\end{array}$ & $\begin{array}{l}\text { Senior High } \\
\text { School }\end{array}$ & $\begin{array}{l}\text { Language to } \\
\text { Culture }\end{array}$ & $\begin{array}{l}\text { Statistics, } \\
\text { Geometry, } \\
\text { Algebra, }\end{array}$ & \\
\hline 42. & $\begin{array}{l}\text { Seán, Charalam- } \\
\text { bos, Hui-Yu Hsu, } \\
\text { \& Vilma } \\
\text { (2007) }\end{array}$ & $\begin{array}{l}\text { The Treatment Of Addition and Subtraction } \\
\text { Of Fractions In Cypriot, Irish, and Taiwanese } \\
\text { Textbooks. }\end{array}$ & $\begin{array}{l}\text { Elementary } \\
\text { School }\end{array}$ & $\begin{array}{l}\text { All the Content } \\
\text { and Cover. }\end{array}$ & Fractions & \\
\hline 43. & Sun (2011) & $\begin{array}{l}\text { Variation problems and their roles in the } \\
\text { topic of fraction division in Chinese math- } \\
\text { ematics textbook examples }\end{array}$ & $\begin{array}{l}\text { Elementary } \\
\text { School }\end{array}$ & $\begin{array}{l}\text { Variation } \\
\text { practice and } \\
\text { problems }\end{array}$ & Fractions & \\
\hline 44. & Xin (2007) & $\begin{array}{l}\text { Word Problem Solving Tasks in Textbooks } \\
\text { and Their Relation to Student Performance }\end{array}$ & $\begin{array}{l}\text { Junior High } \\
\text { School }\end{array}$ & $\begin{array}{l}\text { Word Problem } \\
\text { Solving Tasks }\end{array}$ & $\begin{array}{l}\text { Multiplication } \\
\text { and Division }\end{array}$ & \\
\hline
\end{tabular}

Received: May 02, 2017

Accepted: June 23, 2017

Cheng Chieh Chang

Ph.D, Associate Professor, Institute of Education, National Taiwan Ocean University, No.2, Beining Rd., Jhongjheng District, Keelung 20224, Taiwan. E-mail: changjac@mail2000.com.tw

Sari Muthia Silalahi

M.Ed., Master Student, Institute of Education, National Taiwan Ocean University, No.2, Beining Rd., Jhongjheng District, Keelung 20224, Taiwan.

E-mail: sarimuthiasilalahi@gmail.com 